\title{
FAKTOR Yang MeMPengaruhi KeSESUAIAN IMPLEMENTASI DENGaN Rencana Tata Bangunan Dan Lingkungan Dalam Program Penataan Lingkungan Permukiman Berbasis Komunitas Studi Kasus: DeSa Jendi WONOGIRI
}

\author{
Antissia Meuthia Rizky, Winny Astuti, Galing Yudana \\ Program Studi Perencanaan Wilayah dan Kota \\ Jurusan Arsitektur, Fakultas Teknik \\ Universitas Sebelas Maret, Surakarta \\ email: antissiameuthia@gmail.com
}

\begin{abstract}
Jendi village, selected as a pilot project which received the Neighborhood Development program (ND) is the government's effort to solve the poor's problemsbased onimprovementof housing's quality. To achieve the goal, the building implementation should be based on the plan that has been made. So, it makes a question "is the implementation of Jendi Village based on Building and Environmental Planning and how the factors affect the suitability itself."This research uses quantities research methods to analyze the factors that affect the implementation of RTBL Jendi Village. The suitability is found from the analysis which compare the plan and the implementation related with each aspect of planning. To know the factors that affect the implementation of RTBL Jendi Village, the analysis is done using the quantities methods from combination of implementable suitability and the suitable factors of implementation. The research obtain that the implementable suitability with RTBL of Jendi Village has 81,25\% with the suitability from streets, public open space, environment identity concept, the face of the streets, drainage. Factors that affect the implementable suitability with RTBL Jendi Village is communication, human resource, authority, infrastructures and facilities, money, attitude and commitment, bureaucracy structures, and support. And the other factor which not affected with suitability is information resource.

Keywords: Factor that affect the implementable suitability, RTBL, Neighborhood Development
\end{abstract}

\section{PENDAHULUAN}

Permukiman memiliki arti bagian dari lingkungan hidup di luar kawasan lindung, dapat merupakan kawasan perkotaan dan pedesaan, berfungsi sebagai lingkungan tempat tinggal/ hunian dan tempat kegiatan yang mendukung perikehidupan dan penghidupan (UU No.1 tahun 2011). Permukiman di Indonesia dibedakan menjadi dua, yaitu pemukiman desa dan kota. Sebagian penduduk Indonesia saat ini masih bertempat tinggal di kawasan permukiman pedesaan. Kawasan pedesaan menghadapi permasalahanpermasalahan baik internal maupun eksternal

Untuk mengatasi permasalahanpermasalahan kemiskinan melalui peningkatan kualitas permukiman, maka pemerintah membuat program Penataanan Lingkungan Permukiman Berbasis Komunitas (PLPBK) atau Neighbourhood Development.

Desa Jendi yang merupakan salah satu dari 18 desa di Indonesia yang menerima program PLPBK terletak di Kecamatan Selogiri, Kabupaten Wonogiri, Provinsi Jawa Tengah pada tahun 2008. Desa Jendi menerima proyek percontohan (pilot project) PLPBK sebagai hadiah atau reward yang diberikan oleh pemerintah karena Desa Jendi memiliki Badan Keswadayaan Masyarakat (BKM) berkualifikasi sebagai BKM mandiri. Untuk mencapai tujuan penataan lingkungan permukiman dan mengentaskan kemiskinan di 
Desa Jendi implementasi seharusnya dilakukan sesuai dengan rencana.

Dengan kondisi seperti ini memunculkan pemikiran apakah implementasi rencana di Desa Jendi sesuai dengan RTBL dan apakah faktor-faktor yang mempengaruhi kesesuaian tersebut.

Tujuan dari penelitian ini adalah untuk mengetahui faktor yang mempengaruhi kesesuaian antara implementasi dengan Rencana Tata Bangunan dan Lingkungan di Desa Jendi Kecamatan Selogiri Kabupaten Wonogiri dalam program Penataan Lingkungan Permukiman Berbasis Komunitas.

\section{METODE}

Analisis dalam penelitian ini dilakukan dua kali. Analisis pertama dilakukan untuk mengetahui kesesuaian antara implementasi dengan RTBL Desa Jendi dengan menggunakan metode skoring. Analisis kedua dilakukan untuk mengetahui faktor yang berpengaruh terhadap implementasi RTBL Desa Jendi dengan menggunakan metode kuantitatif dari hasil penggabungan kesesuaian implementasi dengan faktor kesesuaian implementasi.

\section{HASIL DAN PEMBAHASAN \\ 3.1 Kesesuaian Implementasu dengan RTBL Desa Jendi}

Kesesuaian implementasi dengan RTBL Jendi dilihat dari setiap lokasi, jumlah dan ukuran pada masing-masing aspek-aspek perencanaan. Analisis kesesuaian dilakukan dengan membandingkan antara implementasi yang telah dilakakukan dengan RTBL yang disusun dalam program PLPBK Desa Jendi.

Dalam pelaksanaan implementasi RTBL Desa Jendi terdapat kesesuaian dalam implementasi jaringan jalan, ruang terbuka umum, identitas lingkungan, wajah jalan dan jaringan drainase. Serta ketidaksesuaian terdapat pada peruntukan lahan mikro, sirkulasi pejalan kaki dan jaringan persampahan (lihat Lampiran 1. Faktor Kesesuaian Implementasi dengan RTBL). Berdasarkan metode, dapat dirumuskan bahwa kesesuaian implementasi dengan RTBL Desa Jendi memiliki presentase sebesar $81,25 \%$
A. Faktor
Kesesuaian

Implementasi RTBL Desa Jendi

Faktor kesesuaian implementasi RTBL Desa Jendi di lihat dari faktor-faktor yang ada pada saat melakukan implementasi. Faktor tersebut dilihat pada setiap aspek perencanaan yang dilakukan (lihat Lampiran 2. Faktor Kesesuaian Implementasi dengan RTBL)

\subsection{Faktor yang Mempengaruhi Kesesuaian Implementasi dengan RTBL Desa Jendi}

Analisis ini bertujuan untuk mengatahui faktor apa saja yang mempengaruhi kesesuaian implementasi pada setiap aspek yang ada pada RTBL Desa Jendi. Analisis faktor yang mempengaruhi kesesuaian dilakukan pada setiap aspek implementasi.

Implementasi peruntukan lahan mikro tidak dilaksanakan sesuai dengan RTBL Desa Jendi walaupun semua faktor mendukung seperti adanya komunikasi, adanya tokoh masyakat yang dipercaya untuk melaksanakan, adanya informasi, kewenangan penuh pada pelaksana, terdapat sarana dan prasarana yang memadai, tersedia pendanaan yang cukup, adanya sikap dan komitmen dari pelaksana, pelaksana melakukan implementasi sesuai dengan tugasnya dan tedapat dukungan dar pihak luar. Sehingga walaupun semua faktor yang mendukung akan tetapi belum mampu membuat rencana dapat diimplementasikan sesuai dengan RTBL Desa Jendi. Seperti yang dikatakan Jan Marse dalam Wahab (1990), implementasi yang tidak sesuai dapat disebabkan oleh faktor-faktor tersebut.

Kesesuaian antara implementasi dengan rencana sistem jaringan jalan karena adanya faktor-faktor seperti pelaksana pembangunan merupakan tokoh yang dipercaya masyarakat untuk melaksanakan perbaikan jalan, pelaksana memiliki kewenangan yang penuh dalam 
melaksanakan pembangunan dan melaksanakan sesuai dengan tugasnya, terdapat sarana dan prasarana yang mendukung dalam melaksanakan implementasi, adanya pendanaan dalam pelaksanaan, serta terdapat dukungan dari pemerintah khusunya DPU yang turut berpartisipasi dalam implementasi. Walaupun faktor komunikasi, sumber daya manusia, dan informasi masih kurang, pelaksanaan pembangunan jaringan jalan masih sesuai dengan rencana.

Ketidaksesuaian implementasi
jaringan pejalan kaki dipengaruhi kurangnya komunikasi antara perencana dengan pelaksana pembangunan, tidak adanya informasi terkait rencana jaringan pejalan kaki, kurangnya sikap dan komitmen pelaksana pembangunan, dan tidak adanya dukungan dari pihak luar terkait rencana tersebut.

Kesesuaian implementasi rencana ruang terbuka umum Desa Jendi dipengaruhi oleh adanya tokoh masyarakat yang paham, adanya kewenangan yang jelas, tersedia sarana dan prasarana, sikap dan komitmen masyarakat, struktur birokrasi, dan adanya dukungan dari pihak luar.

Kesesuaian implementasi identitas lingkungan dikarenakan adanya tokoh masyarakat yang paham terkait identitas lingkungan, adanya kewenangan, adanya sarana dan prasarana pembangunan gerbang, adanya sikap dan komitmen dari pelaksana pembangunan, adanya struktur birokrasi, dan dukungan dari pihak luar.

Kesesuaian implementasi wajah jalan dikarenakan adanya kewenangan, sarana dan prasarana yang memadai, pendanaan yang cukup, sikap dan komitmen dari pelaksana untuk menyelesaikan rencana wajah jalan, pelaksana melaksanakana pembangunan sesuai dengan tugasnya dan adanya dukungan dari pihak luar.

Kesesuaian antara implementasi dengan rencana sistem jaringan drainase dikarenakan adanya faktor-faktor seperti pelaksana pembangunan merupakan tokoh yang dipercaya masyarakat, pelaksana memiliki kewenangan yang penuh dalam melaksanakan pembangunan dan melaksanakan sesuai dengan tugasnya, terdapat sarana dan prasarana yang mendukung dalam melaksanakan imlementasi, serta adanya pendanaan dalam pelaksanaan. Seperti yang dikatakan Edward III, Merilee S (1980), kesesuaian terjadi karena faktor-faktor tersebut beroprasi dan saling terkait satu sama lainnya.

Kegiatan pengolahan dan pemanfaatan tersebut tidak terlaksana sebab tidak adanya kemauan dari masyarakat untuk melaksanakan pengelolaan sampah, tidak adanya pendanaan dan dukungan yang dapat memacu masyarakat, tidak adanya komunikasi antar masyarakat, dan masyarakat merasa kurang memiliki keahlian dalam hal daur ulang sampah.

Sedangkan, faktor-faktor yang berpengaruh dalam implementasi RTBL Desa Jendi terdapat delapan faktor yang mempengaruhi kesesuaian implementasi dengan RTBL Desa Jendi (lihat Lampiran 3. Faktor yang Mempengaruhi Kesesuaian Implementasi dengan RTBL). Faktor tersebut adalah komunikasi, sumber daya manusia, sumber daya kewenangan, sumber daya sarana dan prasarana, sumber daya pendanaan, sikap dan komitmen, struktur birokrasi, serta dukungan. Sedangkan faktor informasi merupakan faktor yang tidak berpengaruh terhadap kesesuaian.

Keberadaan faktor yang paling tinggi pengaruhnya dalam kesesuaian implementasi dengan RTBL adalah sumber daya kewenangan, sarana dan prasarana serta struktur birokrasi. Adanya BKM Ngudi Mulyo, TIPP, dan TPP Desa Jendi yang diberikan kewenangan yang jelas dan pembagian tugas melalui struktur organisasi yang dijalankan dengan baik dalam proses pelaksanaan pembangunan membuat implementasi yang dilaksanakan dapat sesuai dengan RTBL yang telah dibuat. 


\begin{abstract}
Sedangkan faktor yang tidak berpengaruh terhadap kesesuaian implementasi adalah faktor sumber daya informasi. Informasi terkait rencana menjadi hal yang sangat dibutuhkan dalam mengarahkan pelaksana pembangunan dan masyarakat koridor permukiman untuk mengimlementasikan sesuai rencana yang tertuang di RTBL. Media informasi rencana berupa papan pengumuman dan media internet blogspot yang ada masih dianggap belum mencukupi dalam upaya menginformasikan rencana yang tertuang dalam RTBL.

Kondisi tersebut menunjukan bahwa faktor yang ada saat implementasi yakni komunikasi, sumber daya manusia, sumber daya kewenangan, sumber daya sarana dan prasarana, sumber daya pendanaan, sikap dan komitmen, struktur birokrasi dan dukungan akan berpengaruh terhadap kesesuaian antara implementasi dengan RTBL Desa Jendi dan faktor tertentu yakni informasi,tidak berpengaruh terdadap kesesuaian implementasi sebagaimana yang dijelaskan oleh Edward III, Grindle 1980 dan Jan Marse dalam Wahab 1990.
\end{abstract}

\section{KESIMPULAN}

Berdasarkan penelitian yang telah dilakukan, dapat disimpulkan bahwa kesesuaian antara implementasi dengan Rencana Tata Bangunan dan Lingkungan Desa Jendi secara keseluruhan bernilai sesuai dengan prosentase kesesuaian $81,25 \%$ apabila dilihat dari kesesuaian lokasi, kesesuaian jumlah dan kesesuaian ukuran pada setiap aspek perencanaan yang ada di Desa Jendi. Namun, apabila ditinjau dari masing-masing aspek perencanaannya, terdapat kesesuaian pada jaringan jalan, ruang terbuka umum, identitas lingkungan, wajah jalan dan jaringan drainase. Serta ketidaksesuaian terdapat pada peruntukan lahan mikro, sirkulasi pejalan kaki dan jaringan persampahan.

Dalam implementasi yang dilakukan sebagai upaya mewujudkan kawasan Desa Jendi yang bertatanan kehidupan masyarakat yang harmonis dengan lingkungan hunian yang sehat, tertib, selaras, berjati diri dan lestari memiliki faktor yang berpengaruh terhadap masing-masing aspek perencanaan. Faktor tersebut adalah komunikasi, sumber daya manusia, sumber daya kewenangan, sumber daya sarana dan prasarana, sumber daya pendanaan, sikap dan komitmen, struktur birokrasi serta dukungan.

\section{REFERENSI}

Edward III, George C (edited). 1984. Public Police Implementing. London-England: Jai Press Inc.

Grindle, Merille S. (ed). 1980. Politic and Policy Implementation in the Third Word. New Jersey: Princeton University Press.

Undang-undang Republik Indonesia Nomor 1 Tahun 2011 tentang Perumahan dan Kawasan Permukiman

Wahab, Solichin. 1990. Analisa Kebijaksanaan Dari Formulasi Ke Implementasi Kebijaksanaan Negara. Malang: Bumi Aksara. 
Antissia Meuthia Rizky, Winny Astuti, Galing Yudhana, Faktor yang Mempengaruhi Kesesuaian Implementasi ...

\section{LAMPIRAN}

Lampiran 1. Faktor Kesesuaian Implementasi dengan RTBL

\begin{tabular}{|l|l|}
\hline Aspek & Kesesuaian \\
\hline Peruntukan lahan mikro & Tidak sesuai \\
\hline Jaringan jalan & Sesuai \\
\hline Sirkulasi pejalan kaki & Tidak sesuai \\
\hline Ruang terbuka umum & Sesuai \\
\hline Identitas lingkungan & Sesuai \\
\hline Wajah jalan & Sesuai \\
\hline Jaringan drainase & Sesuai \\
\hline Jaringan persampahan & Tidak sesuai \\
\hline
\end{tabular}

Sumber: Hasil Analisis, 2015

Lampiran 2. Faktor Kesesuaian Implementasi dengan RTBL

\begin{tabular}{|l|c|c|c|c|c|c|c|c|c|}
\hline \multirow{2}{*}{ Aspek } & \multicolumn{9}{|c|}{ Faktor } \\
\cline { 2 - 10 } & a & b & c & d & e & f & g & h & i \\
\hline $\begin{array}{l}\text { Peruntukan } \\
\text { mikro }\end{array}$ & 3 & 3 & 3 & 3 & 3 & 3 & 3 & 3 & 3 \\
\hline Jaringan jalan & 2 & 3 & 2 & 3 & 3 & 3 & 3 & 3 & 3 \\
\hline Sirkulasi pejalan kaki & 2 & 3 & 1 & 3 & 3 & 3 & 2 & 3 & 1 \\
\hline $\begin{array}{l}\text { Ruang terbuka } \\
\text { umum }\end{array}$ & 2 & 3 & 2 & 3 & 3 & 2 & 3 & 3 & 3 \\
\hline Identitas lingkungan & 2 & 3 & 2 & 3 & 3 & 3 & 3 & 3 & 3 \\
\hline Wajah jalan & 2 & 1 & 1 & 3 & 3 & 3 & 3 & 3 & 3 \\
\hline Jaringan drainase & 3 & 3 & 3 & 3 & 3 & 2 & 3 & 3 & 1 \\
\hline $\begin{array}{l}\text { Jaringan } \\
\text { persampahan }\end{array}$ & 2 & 2 & 3 & 3 & 3 & 2 & 1 & 3 & 1 \\
\hline
\end{tabular}

Sumber: Hasil Analisis, 2015

Keterangan tabel:

1: Faktor tidak berpengaruh

2: Faktor kurang berpengaruh

3: Faktor berpengaruh

a: Komunikasi

b: Sumber Daya Manusia

c: Sumber Daya Informasi

d: Sumber Daya Kewenangan

e: Sumber Daya Sarana dan Prasarana

f: Sumber Daya Pendanaan

g: Sikap dan Komitmen

h: Struktur Birokrasi

i: Dukungan
Lampiran 3. Faktor yang Mempengaruhi

Kesesuaian Implementasi dengan RTBL

\begin{tabular}{|l|c|c|c|c|c|c|c|c|c|}
\hline \multirow{2}{*}{\multicolumn{1}{c|}{ Aspek }} & \multicolumn{7}{|c|}{ Faktor } \\
\cline { 2 - 9 } & $\mathbf{a}$ & $\mathbf{b}$ & $\mathbf{c}$ & $\mathbf{d}$ & $\mathbf{e}$ & $\mathbf{f}$ & $\mathbf{g}$ & $\mathbf{h}$ & $\mathbf{i}$ \\
\hline $\begin{array}{l}\text { Peruntukan lahan } \\
\text { mikro }\end{array}$ & 3 & 3 & 3 & 3 & 3 & 3 & 3 & 3 & 3 \\
\hline Jaringan jalan & 4 & 4 & 4 & 6 & 6 & 6 & 6 & 6 & 6 \\
\hline Sirkulasi pejalan kaki & 2 & 3 & 1 & 3 & 3 & 3 & 2 & 3 & 1 \\
\hline $\begin{array}{l}\text { Ruang terbuka } \\
\text { umum }\end{array}$ & 4 & 6 & 2 & 6 & 6 & 4 & 6 & 6 & 6 \\
\hline Identitas lingkungan & 4 & 6 & 4 & 6 & 6 & 4 & 6 & 6 & 6 \\
\hline Wajah jalan & 4 & 2 & 2 & 6 & 6 & 6 & 6 & 6 & 6 \\
\hline Jaringan drainase & 6 & 6 & 6 & 6 & 6 & 4 & 6 & 6 & 2 \\
\hline $\begin{array}{l}\text { Jaringan } \\
\text { persampahan }\end{array}$ & 2 & 3 & 3 & 3 & 3 & 2 & 1 & 3 & 1 \\
\hline \multicolumn{1}{|c|}{ Jumlah } & $\mathbf{2 9}$ & $\mathbf{3 4}$ & 27 & $\mathbf{3 9}$ & $\mathbf{3 9}$ & $\mathbf{3 4}$ & $\mathbf{3 6}$ & $\mathbf{3 9}$ & $\mathbf{3 1}$ \\
\hline
\end{tabular}

Sumber: Hasil Analisis, 2015

Keterangan tabel :

1: Faktor tidak berpengaruh

2: Faktor kurang berpengaruh

3: Faktor berpengaruh

a: Komunikasi

b: Sumber Daya Manusia

c: Sumber Daya Informasi

d: Sumber Daya Kewenangan

e: Sumber Daya Sarana dan Prasarana

f: Sumber Daya Pendanaan

g: Sikap dan Komitmen

h: Struktur Birokrasi

i: Dukungan 